\title{
Accumulation of End Products in Source Leaves Affects Photosynthetic Rate in Peach via Alteration of Stomatal Conductance and Photosynthetic Efficiency
}

\author{
Jieshan Cheng \\ Institute of Botany, the Chinese Academy of Sciences, Beijing 100093, People's Republic of China and \\ Graduate College, the Chinese Academy of Sciences, Beijing 100093, People's Republic of China \\ Peige Fan, Zhenchang Liang, Yanqiu Wang, and Ning Niu \\ Institute of Botany, the Chinese Academy of Sciences, Beijing 100093, People's Republic of China \\ Weidong Li \\ School of Chinese Pharmacy, Beijing University of Chinese Medicine, Beijing 100102, People's \\ Republic of China

\begin{abstract}
Shaohua $\mathbf{L i}^{1}$
Wuhan Botanical Garden, the Chinese Academy of Sciences, Wuhan 430074, People's Republic of China
\end{abstract}

\begin{abstract}
Additional Index words. Prunus persica, source-sink relationship, leaf temperature, fluorescence response, enzyme activities

Abstract. In 'Beijing 24' peach [Prunus persica (L.) Batch] trees, a series of source leaves with differing levels of end products were created by retaining fruit ("+fruit"), removing fruit ("-fruit"), or reducing the light period. To alter the light period, leaves were covered with a bag made of brown inner paper and outer silver paper, which was then removed at different times the next day. The highest level of end products were obtained by fruit removal, while reducing the light period resulted in a lower level than "+fruit." Net photosynthetic rate $\left(P_{n}\right)$ and stomatal conductance $\left(g_{\mathrm{s}}\right)$ decreased, but leaf temperatures $\left(\mathrm{T}_{\text {leaf }}\right)$ increased, following an increase in end product levels in leaves. After the "-fruit" treatment, reduced $P_{n}$ was correlated with lower $g_{s}$, and $T_{\text {leaf }}$ increase was concomitant with decreases in maximal quantum yield of photosystem II $\left(F_{v} / F_{m}\right)$, actual photochemical efficiency of photosystem II (ФPSII), and photochemical quenching, and with an increase in nonphotochemical quenching. However, there were no significant differences in chlorophyll fluorescence between "+fruit" and the two treatments reducing the light period. The $\Phi$ PSII decreased following an increase in foliar sorbitol level, and it linearly decreased as sucrose and starch increased. Although fruit removal resulted in a significant accumulation of sucrose, sorbitol, and starch in leaves throughout the day, the extractable activities of several important enzymes involved in carbohydrate leaf storage and translocation did not decrease. Therefore, instead of feedback regulation by the accumulation of end products in source leaves, a high $T_{\text {leaf }}$ induced by decreased stomatal aperture may play a key role in regulation of photosynthesis by limiting the photochemical efficiency of the PSII reaction centers under high levels of the end products in peach leaves.
\end{abstract}

Crop yield and fruit quality in fruit trees are highly dependent on efficient capture of solar energy and subsequent allocation of photoassimilate. Source-sink relationships are important factors influencing these allocation patterns. Fruit constitute the main sink for photoassimilates during the fruit growth period. Removing or retaining fruit has often been used in studies of plant source-sink relationships (Syvertsen et al., 2003; Vaast et al., 2005). Reduced photosynthetic rates under

Received for publication 3 Apr. 2009. Accepted for publication 10 Nov. 2009 The research was supported by the National Natural Science Foundation of China (No. 30370986) and by the Science Foundation of the President of the Chinese Academy of Sciences. We thank Prof. Douglas D. Archbold, Univ. of Kentucky, and Prof. W. Loescher, Michigan State Univ. for critical review of the manuscript.

We thank Yanfeng Xing (Director, Fruit Office, Pinggu District, Beijing, China) for the use of the experimental orchard facilities.

${ }^{1}$ Corresponding author. E-mail: shhli@wbgcas.cn low sink demand have often resulted in end product accumulation. This accumulation of end products has been often cited as the reason for the decline of $\mathrm{P}_{\mathrm{n}}$ (Iglesias et al., 2002; Paul and Foyer, 2001; Wu et al., 2008; Zhou and Quebedeaux, 2003). This influence of end product accumulation has been considered a direct feedback mechanism regulating photosynthesis (Paul and Pellny, 2003). However, this conclusion is controversial (Eliezer and Huber, 1992; Stitt, 1991). For example, photosynthesis was not influenced in some species, although there was accumulation of end products in source leaves in response to low sink demand (Lunn and Hatch, 1995; Nautiyal et al., 1999; Roper et al., 1988). In addition, some recent studies with peach (Li et al., 2007) and coffee (Coffea arabica L.) trees (DaMatta et al., 2008) showed that low sink demand created by removing fruit reduced $P_{n}$ with accumulation of the end products, but there was no influence on in vitro activity of key enzymes in the biosynthetic pathways of the end products. 
However, there have been few studies on the influence of end product accumulation on photosynthetic efficiency and activities of related enzymes.

Source-sink relationships can be also modified by reducing or prolonging the light period. Reducing the light period decreased end product amount in source leaves, and this was similar to the effect of increasing sink demand (Li et al., 2007). By removing fruit and reducing the light period, respectively, it may be possible to create a range of source leaves with differing end product levels. This would be a valuable method for investigating the possible feedback effect of end product levels on photosynthetic efficiency and the relationship between the end products and activities of related enzymes.

A positive linear relationship was observed between stomatal conductance $\left(g_{\mathrm{s}}\right)$ and $\mathrm{P}_{\mathrm{n}}$ in previous studies, showing that stomatal closure was an important factor in the decline in photosynthesis with low sink demand (Cheng et al., 2008; Li et al., 2001). Increased $\mathrm{T}_{\text {leaf }}$ following a reduction in stomatal aperture has been proposed as a critical factor in regulating photosynthesis under low sink demand in fruit trees ( $\mathrm{Li}$ et al., $2005)$. These changes in $T_{\text {leaf }}$ have also been related to reduced $\mathrm{F}_{\mathrm{v}} / \mathrm{F}_{\mathrm{m}}$ (Jifon and Syvertsen, 2003). This article presents the results of studies on the short-term effect of end product accumulation on peach leaf $\mathrm{P}_{\mathrm{n}}$, focusing on ФPSII and the activities of related enzymes. Also, the responses of $\mathrm{P}_{\mathrm{n}}, g_{\mathrm{s}}$, and $\Phi P S I I$ to end product levels in leaves were analyzed.

\section{Materials and Methods}

EXPERIMENTAL SITES AND MATERIALS. The experiment was conducted in Pinggu District, Beijing, China, during the 2006 growing season. The peach cultivar used was Beijing 24 , which matures during early September. Trees, grafted on wild peach rootstocks, were planted $2 \mathrm{~m}$ apart within rows and $5 \mathrm{~m}$ apart between rows in Spring 1998. They were trained to a "Y" training system and were pruned by the long pruning method in winter (Li et al., 1994).

SourCE-SinK MANIPUlation. During the final stage of rapid fruit growth (on 22 Aug. 2006), 1-year-old shoots located on the southwest and southeast sides of 15 to 20 trees in the outer part of the canopy were used as the units for source-sink manipulation. These previous-season shoots were 1.4 to $1.7 \mathrm{~m}$ aboveground, and were selected according to their uniformity in length $(40-50 \mathrm{~cm})$ and growth status (at least one new shoot $>30 \mathrm{~cm})$.

Each 1-year-old shoot, supporting one fruit and one new shoot of 10 fully developed leaves retained by topping and removal of smaller basal leaves, was considered a plot. The export of assimilates was strictly controlled by girdling the base and top parts of the previous-season shoots to control the exchange of assimilates between treated and nonexperimental parts of the tree.

Four treatments were applied in this study: 1) "+fruit" treatment (control), 2) "-fruit" treatment, 3) a shoot supporting a fruit, covered with a bag made of brown inner paper and outer silver paper in the late afternoon of 22 Aug. with the bags removed at $0930 \mathrm{HR}$ ("0930 HR bag removal") on 23 Aug., and 4) a shoot supporting a fruit, covered with the same bag as used in the previous treatment, but with the bags removed at $1130 \mathrm{HR}$ ("1130 HR bag removal") on 23 Aug. A total of five plots for each treatment was used for the measurements of photosyn- thetic parameters and chlorophyll fluorescence, and 15 to 20 plots were used for the measurements of sugar content and enzyme activities.

Measurement of PHOtosynthetic PARAMETERS AND CHLOROPHYLl FluORESCENCE. Photosynthetic gas exchange and chlorophyll fluorescence response of five leaves per treatment (one leaf per replicate) were measured between 0700 and $1700 \mathrm{HR}$ on an hourly basis on 23 Aug. 2006, the day after initiating source-sink manipulation. For the "0930 HR bag removal" and "1130 HR bag removal" treatments, measurements were made $30 \mathrm{~min}$ after bag removal to allow for light adaptation by the leaves.

$\mathrm{P}_{\mathrm{n}}$ was measured with a portable photosynthesis system (LI-6400; LI-COR, Lincoln, NE) and photosynthetically active radiation $(P A R), g_{\mathrm{s}}$, transpiration rate $(\mathrm{E})$, intercellular carbon dioxide concentration $\left(\mathrm{C}_{\mathrm{i}}\right)$, and $\mathrm{T}_{\text {leaf }}$ were obtained simultaneously when $\mathrm{P}_{\mathrm{n}}$ was measured.

Chlorophyll fluorescence parameters were measured with a plant efficiency analyzer [PEA (Hansatech, Norfolk, UK)] and a fluorescence monitoring system (FMS-2; Hansatech). After a 30-min dark adaptation period, minimum fluorescence $\left(\mathrm{F}_{0}\right)$, maximum fluorescence $\left(\mathrm{F}_{\mathrm{m}}\right)$, the steady-state fluorescence $\left(\mathrm{F}_{\mathrm{s}}\right)$, and $\mathrm{F}_{\mathrm{v}} / \mathrm{F}_{\mathrm{m}}$, were measured by the PEA. The PEA was also used to estimate the predawn value of $\mathrm{F}_{\mathrm{m}}$. The FMS-2 was used to determine the maximum fluorescence level in the light-adapted state $\left(\mathrm{F}_{\mathrm{m}}{ }^{\prime}\right)$, the minimal fluorescence level in the light-adapted state $\left(\mathrm{F}_{0}{ }^{\prime}\right)$, and the efficiency of excitation capture by open PSII reaction centers $\left(\mathrm{F}_{\mathrm{v}}{ }^{\prime} / \mathrm{F}_{\mathrm{m}}{ }^{\prime}\right)$.

The following calculations were made: (1) photochemical quenching $(\mathrm{qP})=\left(\mathrm{F}_{\mathrm{m}}{ }^{\prime}-\mathrm{F}_{\mathrm{s}}\right) /\left(\mathrm{F}_{\mathrm{m}}{ }^{\prime}-\mathrm{F}_{0}{ }^{\prime}\right)$, and nonphotochemical quenching $(\mathrm{NPQ})=\left(\mathrm{F}_{\mathrm{m}} / \mathrm{F}_{\mathrm{m}}{ }^{\prime}\right)-1 ;(2)$ ФPSII $=\left(\mathrm{F}_{\mathrm{m}}{ }^{\prime}-\mathrm{F}_{\mathrm{s}}\right) / \mathrm{F}_{\mathrm{m}}{ }^{\prime}$ (Genty et al., 1989).

Carbohydrate analysis ANd Enzyme assay. Leaves from five plots of each treatment were harvested every $2 \mathrm{~h}$ between 0700 and $1700 \mathrm{HR}$ (for the bagging treatments, leaves were sampled starting at 1000 or $1200 \mathrm{HR}$, respectively), and the midrib of each leaf was removed. One half of the leaf was used for carbohydrate analysis and the other half was used for enzyme extraction and biochemical analyses. Leaf samples were frozen immediately in liquid nitrogen and were kept at $-80{ }^{\circ} \mathrm{C}$ until analysis.

For soluble carbohydrate extraction, about $1.5 \mathrm{~g}$ of fresh weight of leaves was ground to a fine powder in liquid nitrogen using a mortar and pestle. The powder was extracted three consecutive times in $10 \mathrm{~mL}$ of $80 \%$ ethanol in a water bath at $80{ }^{\circ} \mathrm{C}$ for $10 \mathrm{~min}$ each time, and solutions were centrifuged (Sigma Laborzentrifugen, Osterode, Germany) at 19,118 $g_{\mathrm{n}}$ for $10 \mathrm{~min}$ after each extraction. The combined ethanol supernatants for each sample were evaporated to dryness in a water bath at $85{ }^{\circ} \mathrm{C}, 1.5 \mathrm{~mL}$ of double distilled water was added, and samples were placed in a rotary shaker (THZ-C-1; Taicang Instrument, Jiangsu, China) for $1 \mathrm{~h}\left(4^{\circ} \mathrm{C}\right)$. The solution was then centrifuged at $19,118 g_{\mathrm{n}}$ for $10 \mathrm{~min}$, the supernatant was passed though a SEP-C18 cartridge (Supelclean ENVI C18 SPE; Supelco, Bellefonte, PA) and filtered through a $0.22-\mu \mathrm{m}$ filter, and the filtered solution was taken for the measurement of soluble carbohydrates.

Sorbitol, glucose, fructose, and sucrose were separated by high-performance liquid chromatography [HPLC (Dionex, Sunnyvale, CA)], and they were detected using a Shodex RI101 refractive index detector with reference cell maintained at $40{ }^{\circ} \mathrm{C}$ (Dionex). A Transgenomic CARB Sep Coregel 87C 
column $(300 \times 7.8 \mathrm{~mm}$ i.d., $10 \mu \mathrm{m}$ particle size; Dionex $)$ with a guard column cartridge was used. The column was maintained at $85{ }^{\circ} \mathrm{C}$ with a TCC-100 thermostatted column compartment (Dionex). Degassed, distilled, deionized water was used at a flow-rate of $0.6 \mathrm{~mL} \cdot \mathrm{min}^{-1}$ as the mobile phase. The injection volume was $10 \mu \mathrm{L}$. The Chromeleon chromatography data system (Dionex) was used to integrate peak areas according to external standard solution calibrations (sugar reagents were purchased from Sigma-Aldrich, St. Louis). Starch remaining in the tissue was extracted and measured according to $\mathrm{Li}$ and $\mathrm{Li}$ (2005).

The enzyme extracts were obtained as follows: $1.0 \mathrm{~g}$ of frozen leaf tissue was ground to a fine powder in liquid nitrogen with quartz sand. Extraction buffer was added to the ground sample, and the slurry was ground to mix thoroughly. The extraction buffer contained $50 \mathrm{mmol} \cdot \mathrm{L}^{-1} \mathrm{~N}$-2-hydroxyethylpiperazine-N-ethane-sulphonicacid [Hepes- $\mathrm{NaOH}(\mathrm{pH}$ 7.5, Sigma-Aldrich)], $10 \mathrm{mmol} \cdot \mathrm{L}^{-1}$ magnesium chloride hexahydrate $\left[\mathrm{MgCl}_{2}\right.$ (Sigma-Aldrich)], $1.0 \mathrm{mmol} \cdot \mathrm{L}^{-1}$ disodium ethylenediamine tetraacetate [EDTANa 2 (Sigma-Aldrich)], 2.5 $\mathrm{mmol} \cdot \mathrm{L}^{-1}$ dithiothreitol [DTT (Sigma-Aldrich)], 0.05\% $t$-octylphenoxypolyethoxyethanol (Triton X-100, Sigma-Aldrich), and $0.1 \%$ bovine serum albumin [BSA (Sigma-Aldrich)]. The homogenate was filtered through four layers of gauze, and the filtrate was centrifuged at $13,000 g_{n}$ for $10 \mathrm{~min}$ at $2{ }^{\circ} \mathrm{C}$. The supernatant was dialyzed immediately by a 10 -fold volume of diluted extraction buffer (minus Triton X-100) for $20 \mathrm{~h}$ at $4{ }^{\circ} \mathrm{C}$, and the dialyzate was changed one time. In these analyses, leaves were not allowed to thaw before grinding in extraction buffer, and particular care was taken to work rapidly once the material had been taken up in buffer at $4{ }^{\circ} \mathrm{C}$. The enzyme extracts after dialysis were used for all enzyme assays.

Aldose-6-phosphate reductase [A6PR (EC 1.1.1.200)] activity was assayed in the direction of synthesis following the oxidation of nicotinamide adenine dinucleotide phosphate [NADPH (reduced form, Sigma-Aldrich)] in the presence of glucose-6-P at $340 \mathrm{~nm}$, as described by Merlo and Passera (1991). The reaction mixture contained $0.1 \mathrm{~mol} \cdot \mathrm{L}^{-1}$ Tris (hydroxymethyl) aminomethane [Tris- $\mathrm{HCl}(\mathrm{pH} 8.8$, SigmaAldrich)], $0.1 \mathrm{mmol} \cdot \mathrm{L}^{-1} \mathrm{NADPH}, 50 \mathrm{mmol} \cdot \mathrm{L}^{-1}$ glucose-6-P, and $50 \mu \mathrm{L}$ of extract. One unit of A6PR is defined as the amount of enzyme catalyzing the oxidation of $1.0 \mu \mathrm{mol} \cdot \mathrm{min}^{-1} \mathrm{NADPH}$ at $25{ }^{\circ} \mathrm{C}$ under standard assay conditions. The activity of sorbitol dehydrogenase [SDH (EC 1.1.1.14)] was assayed by following the reduction of nicotinamide adenine dinucleotide $\left[\mathrm{NAD}^{+}\right.$(Sigma-Aldrich)] in the presence of D-sorbitol at 340 $\mathrm{nm}$, according to the method described by Negm and Loescher (1979). The reaction mixture contained $0.1 \mathrm{~mol} \cdot \mathrm{L}^{-1}$ Tris- $\mathrm{HCl}$ (pH 9.0), $1.0 \mathrm{mmol} \cdot \mathrm{L}^{-1} \mathrm{NAD}^{+}, 0.5 \mathrm{~mol} \cdot \mathrm{L}^{-1} \mathrm{D}$-sorbitol, and 0.1 $\mathrm{mL}$ of extract. Sorbitol and glucose-6-phosphate [G-6-P (Sigma-Aldrich)], dissolved in the same buffer as used in the assay, were used to start the reactions.

Sucrose-phosphate synthase [SPS (EC 2.4.1.14)] activity was determined by measuring the conversion rate of fructose-6phosphate [F-6-P (Sigma-Aldrich)] to sucrose-phosphate (S-6P; Sigma-Aldrich), according to the method described by Huber and Israel (1982) with some changes. The assay mixtures (140 $\mu \mathrm{L})$ contained $50 \mathrm{mmol} \cdot \mathrm{L}^{-1}$ Hepes- $\mathrm{NaOH}(\mathrm{pH} 7.5), 10$ $\mathrm{mmol} \cdot \mathrm{L}^{-1} \mathrm{MgCl}_{2}, 5 \mathrm{mmol} \cdot \mathrm{L}^{-1}$ sodium fluoride $(\mathrm{NaF}), 25$ $\mathrm{mmol} \cdot \mathrm{L}^{-1}$ uridine $5^{\prime}$-diphosphoglucose disodium salt [UDPG (Sigma-Aldrich)], $10 \mathrm{mmol} \cdot \mathrm{L}^{-1} \mathrm{~F}-6-\mathrm{P}$, and $80 \mu \mathrm{L}$ of extract. The reaction was stopped after $40 \mathrm{~min}$ at $25^{\circ} \mathrm{C}$ by adding 140 $\mu \mathrm{L}$ of $1.0 \mathrm{~mol} \cdot \mathrm{L}^{-1} \mathrm{NaOH}$. Unreacted F-6-P was destroyed by placing the tubes in boiling water for $10 \mathrm{~min}$. After cooling, 0.5 $\mathrm{mL}$ of $0.1 \%$ resorcinol in $95 \%$ ethanol and $1.5 \mathrm{~mL}$ of $30 \% \mathrm{HCl}$ were added, and the tubes were incubated at $80^{\circ} \mathrm{C}$ for $8 \mathrm{~min}$ and $\mathrm{A}_{520}$ was measured.

ADP glucose-pyrophosphorylase [ADPGPPase (EC 2.7.7.27)] activity was determined by measuring pyrophosphatedependent glucose-1-phosphate formation from adenosine $5^{\prime}$ diphosphoglucose disodium (ADPG; Sigma-Aldrich) at $25^{\circ} \mathrm{C}$ in a total of $1 \mathrm{~mL}$ of solution, according to the procedures described by Rufty et al. (1983). The reaction was started by addition of ADPG to a final concentration of $5 \mathrm{mmol} \cdot \mathrm{L}^{-1}$ and production of NADPH was monitored at $340 \mathrm{~nm}$.

The activities of acid invertase [AI (EC 3.2.1.26)] and neutral invertase [NI (EC 3.2.1.26)] were assayed in a reaction mixture ( $1 \mathrm{~mL}$ ) containing $0.1 \mathrm{~mol} \cdot \mathrm{L}^{-1} \mathrm{Na}$-acetate $(\mathrm{pH} 4.8), 0.1$ $\mathrm{mol} \cdot \mathrm{L}^{-1}$ sucrose, and $0.2 \mathrm{~mL}$ of extract. After incubation of the mixture for $40 \mathrm{~min}$ at $37^{\circ} \mathrm{C}$, the reactions were stopped by addition of $1 \mathrm{~mL}$ of dinitrosalicylic acid reagent (DNS; Beijing Chemical Reagent Corporation, Beijing, China), and reducing sugars released from sucrose were determined according to the method of $\mathrm{Li}$ and $\mathrm{Li}$ (2005). Total amylase activity [(EC 3.1.1.1) and (EC 3.1.1.2)] was assayed in a reaction mixture (1 mL) containing $0.1 \mathrm{~mol} \cdot \mathrm{L}^{-1}$ Na-acetate $(\mathrm{pH} 6.5), 1.5$ $\mathrm{mmol} \cdot \mathrm{L}^{-1} \mathrm{NaF}, 5 \mathrm{mmol} \cdot \mathrm{L}^{-1} \mathrm{Ca}\left(\mathrm{NO}_{3}\right)_{2}, 0.5 \%$ soluble starch, and $0.2 \mathrm{~mL}$ of extract. After incubation at $30{ }^{\circ} \mathrm{C}$ for $40 \mathrm{~min}$, the reaction was ended, and the release of reducing groups was determined as in the invertase assay. In invertase and amylase assays, blanks containing reaction mixtures were incubated with DNS.

DAta ANALysis. A completely randomized design was used with five replicates for each treatment. The data were subjected to analysis of variance (ANOVA), and means were compared by Duncan's new multiple range test or $t$ test (when there were only two groups) using SPSS (version 13.0 for Windows; SPSS, Chicago). Each value of the mean and standard error in the figures represents five replicates of each treatment. Unless otherwise indicated, significant differences among means are given at $P<0.05$.

\section{Results}

Gas EXChange. Fruit removal significantly reduced $\mathrm{P}_{\mathrm{n}}$ from 1000 to $1500 \mathrm{HR}$ and $g_{\mathrm{s}}$ from 9000 to $1600 \mathrm{HR}$, respectively, compared with the "+ fruit" and after removing the bags covering leaves (Fig. 1, A and B). Moreover, the two "bag removal" treatments resulted in significantly higher $\mathrm{P}_{\mathrm{n}}$ and $g_{\mathrm{s}}$ from 1300 to 1500 HR than "+ fruit." A significantly lower E was observed at $0900 \mathrm{HR}$ and 1200 to $1600 \mathrm{HR}$ in the "-fruit" treatment than the other three treatments. However, there were no significant differences in E between "+ fruit" and the two "bag removal" treatments (Fig. 1C).

Opposite to the effect on $\mathrm{P}_{\mathrm{n}}, g_{\mathrm{s}}$ and $\mathrm{E}$, fruit removal significantly increased $T_{\text {leaf }}$ from 1100 to $1500 \mathrm{HR}$ in general compared with the other three treatments. Moreover, a lower $\mathrm{T}_{\text {leaf }}$ was observed for "bag removal" treatments at 1100, 1300, and 1500 HR than "+ fruit" (Fig. 1D).

$\mathrm{C}_{\mathrm{i}}$ changed slowly from 0700 to $1300 \mathrm{HR}$ except for the "-fruit" treatment. For the "-fruit" treatment, the highest $\mathrm{C}_{\mathrm{i}}$ appeared at $1400 \mathrm{HR}$ and then decreased gradually. However, no significant differences in $\mathrm{C}_{\mathrm{i}}$ were found among the treatments until $1400 \mathrm{HR}$. The $\mathrm{C}_{\mathrm{i}}$ of the "-fruit" treatment was significantly 

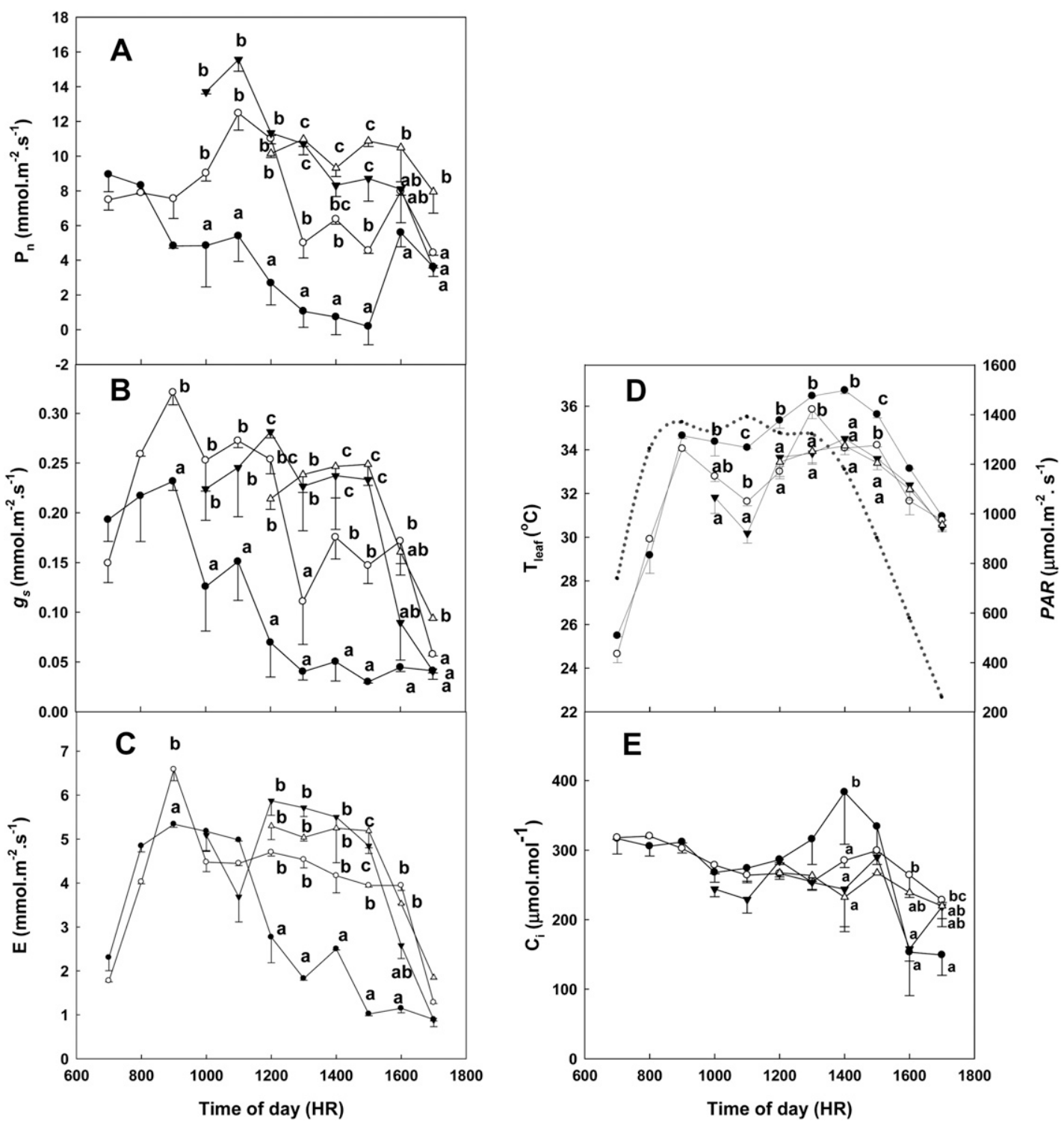

Fig. 1. (A) Diurnal net photosynthetic rate $\left(\mathrm{P}_{\mathrm{n}}\right),(\mathbf{B})$ stomatal conductance $\left(g_{\mathrm{s}}\right),(\mathbf{C})$ transpiration $(\mathrm{E})$, (D) leaf temperature $\left(\mathrm{T}_{\text {leaf }}\right)$ and photosynthetically active radiation $(P A R)$, and $(\mathbf{E})$ intercellular carbon dioxide concentration $\left(\mathrm{C}_{\mathrm{i}}\right)$ in response to fruit removal ("-fruit", - - - , "bag removal at $0930 \mathrm{HR}$ " of fruiting

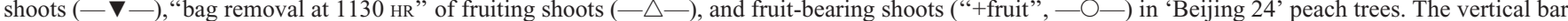
represents \pm SE of each mean $(\mathrm{n}=5)$. Means with different letters at the same time point in the figure are significantly different among the treatments at $P<0.05$ based on Duncan's new multiple range test or $t$ test (when there were only two treatments).

higher than those of other treatments at $1400 \mathrm{HR}$, but was lower than other treatments at 1600 and 1700 HR (Fig. 1E).

Chlorophyll Fluorescence. The "-fruit" treatment significantly decreased $\mathrm{F}_{\mathrm{v}} / \mathrm{F}_{\mathrm{m}}$ (Fig. 2A) from 1100 or $1200 \mathrm{HR}$ to the end of the day, ФPSII (Fig. 2B) at 0900, 1100, and 1400 to $1600 \mathrm{HR}$, qP (Fig. 2C) at 1000 to $1400 \mathrm{HR}$, and $\mathrm{F}_{\mathrm{v}}{ }^{\prime} / \mathrm{F}_{\mathrm{m}}{ }^{\prime}$ at $1400 \mathrm{HR}$ (Fig. 2D), but significantly increased $\mathrm{F}_{0}$ (Fig. 2E) from $1100 \mathrm{HR}$ to the end of the day and NPQ (Fig. 2F) at 1300 to 1700 HR compared with the other three treatments. However, except for $\Phi$ PSII and qP, the other chlorophyll fluorescence parameters showed no response in general to "+fruit" and the two "bag removal" treatments. ФPSII and qP of the "+fruit" treatment were significantly higher than that of the " 930 bag removal" treatment at $1100 \mathrm{HR}$ and 1000 to $1100 \mathrm{HR}$, respectively (Fig. 2, E and F).

Soluble Sugars AND STARCh. Fruit removal and "bag removal" treatments altered the content of soluble sugars and starch in leaves (Fig. 3). The "-fruit" generally resulted in the highest foliar content of soluble sugars and starch among the treatments, and the contents of soluble sugars and starch in "+fruit" leaves were higher than those in the two 'bag removal' treatments. Moreover, the later time of bag removal lowered the content of soluble sugars and starch more than the earlier removal time. The differences in sorbitol and starch content among the treatments remained unchanged throughout the day generally (Fig. 3, A and C). As regards sucrose, fructose and glucose content in the leaves, the magnitude of the differences among treatments sharply decreased after 1300 or 1500 HR (Fig. 3, B, D, and E).

ACTIVIties OF RELATEd ENZYMes OF CARbohydrate METABOLISM. Compared with "+fruit", "-fruit" significantly increased A6PR and SDH activities at $1100 \mathrm{HR}$ and from 0900 to 1100 HR, respectively (Fig. 4). However, "bag removal" treatments did not alter A6PR and SDH activities. As regards 


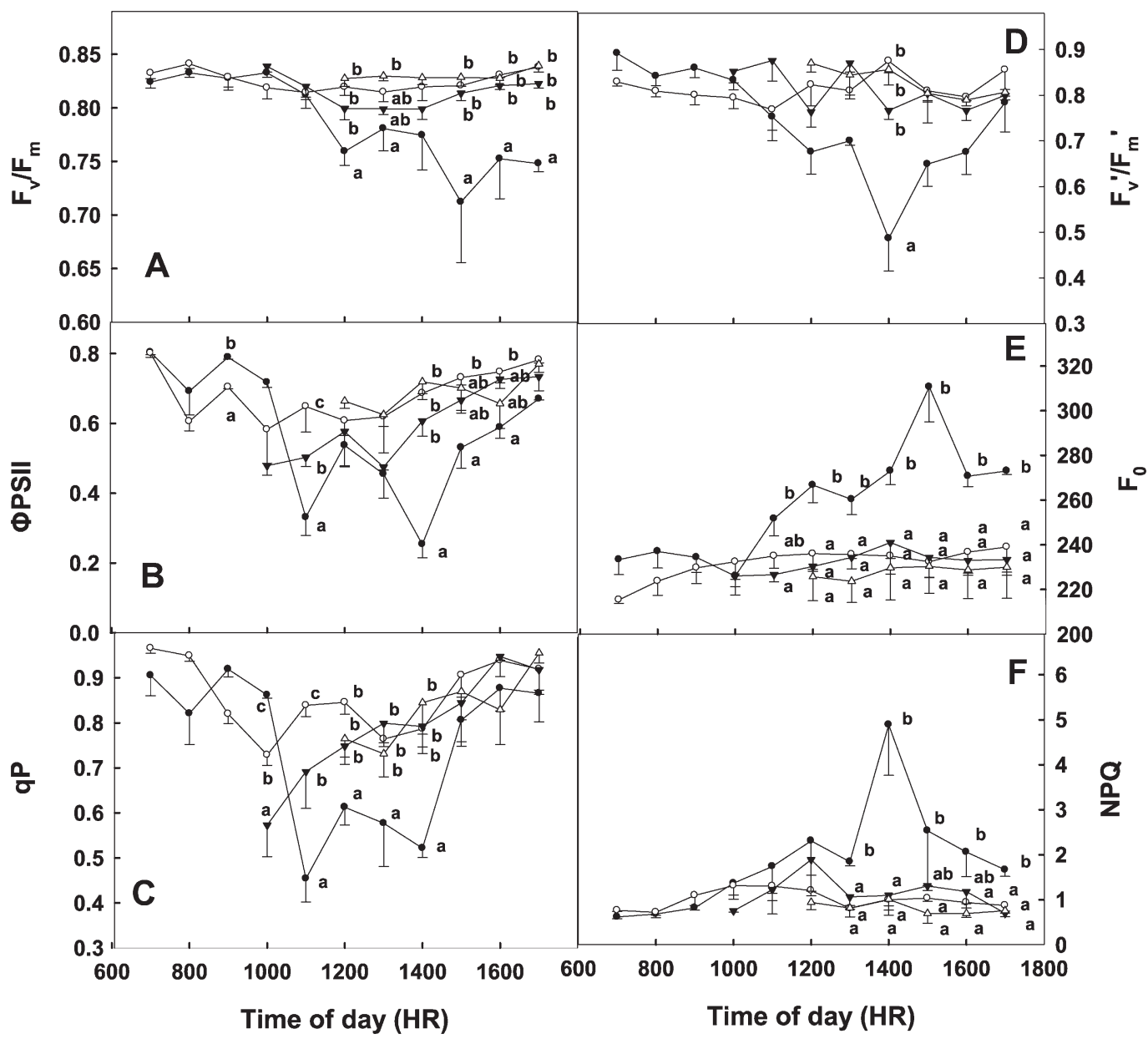

Fig. 2. Diurnal changes in (A) maximal quantum yield of photosystem II $\left(\mathrm{F}_{\mathrm{v}} / \mathrm{F}_{\mathrm{m}}\right),(\mathbf{B})$ actual photochemical efficiency of photosystem II (ФPSII), (C) photochemical quenching $(\mathrm{qP}),(\mathbf{D})$ actual quantum yield of photosystem II $\left(\mathrm{F}_{\mathrm{v}}{ }^{\prime} / \mathrm{F}_{\mathrm{m}}{ }^{\prime}\right),(\mathbf{E})$ minimal fluorescence level after dark-adaptation $\left(\mathrm{F}_{0}\right)$, and $(\mathbf{F})$ nonphotochemical quenching (NPQ) in response to fruit removal ("-fruit", - - - ) "bag removal at $0930 \mathrm{HR}$ " of fruiting shoots (- - -) "bag removal at $1130 \mathrm{HR}$ " of fruiting

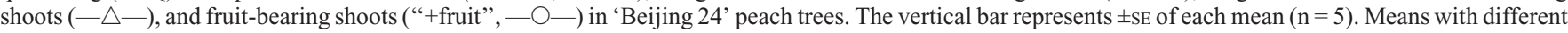
letters at the same time point in the figure are significantly different among the treatments at $P<0.05$ based on Duncan's new multiple range test or $t$ test (when there were only two treatments).

the activities of the other related enzymes of carbohydrate metabolism, no obvious effect of the "-fruit" and "bag removal" treatments were observed (data not shown).

RESPONSE OF $\mathbf{P}_{\mathrm{N}}$ TO $\boldsymbol{G}_{\mathrm{S}}$ AND $\mathbf{T}_{\text {LEAF }} \cdot \mathrm{P}_{\mathrm{n}}$ increased with increased $\mathrm{T}_{\text {leaf }}$ until about $30^{\circ} \mathrm{C}$, remained high between 30 and $34{ }^{\circ} \mathrm{C}$, and then sharply decreased when $\mathrm{T}_{\text {leaf }}$ continued to increase (Fig. 5A). Moreover, when $\mathrm{T}_{\text {leaf }}$ was greater than a critical temperature of about $34^{\circ} \mathrm{C}, \mathrm{P}_{\mathrm{n}}$ was significantly correlated with $g_{\mathrm{s}}\left(r=0.79^{* * *}\right)$ (Fig. 5B).

RESPONSE OF $\mathbf{P}_{\mathrm{N}}, \boldsymbol{G}_{\mathrm{S}}$, ФPSII, AND NPQ TO FOLIAR END PRODUCT AMOUNT. There were significant relationships between $\mathrm{P}_{\mathrm{n}}$ and foliar amounts of end products including sorbitol, sucrose, and starch (Fig. 6). $P_{n}$ decreased following an increase in sorbitol, sucrose, and starch content, indicating that the $P_{n}$ change was somehow affected by their accumulation. The accumulation of the end products was also correlated to $g_{\mathrm{s}}$ (Fig. 7). A high content of sorbitol, sucrose, and starch in leaves was related to lower $g_{\mathrm{s}}$, implied that high content of end products changed $g_{\mathrm{s}}$, presumably by altering osmotic pressure in gourd cell or signal transduction (Fig. 7, A-C), and then lower $g_{\mathrm{s}}$ may have resulted in $\mathrm{P}_{\mathrm{n}}$ decrease. However, significant relationships were only found between $g_{\mathrm{s}}$ and foliar content in starch.
The response of ФPSII to end product amount is shown in Fig. 8. When foliar sorbitol content increased, ФPSII decreased (Fig. 8A). ФPSII also decreased linearly with the sucrose increase (Fig. 8B). However, a relationship between ФPSII and starch content was not apparent (Fig. 8C).

Opposite to ФPSII, NPQ increased following an increase in foliar sorbitol content (Fig. 9A), and NPQ was significantly correlated with sucrose and starch content (Fig. 9, B and C).

\section{Discussion}

Sorbitol, sucrose, and starch are the end products of photosynthesis in many Rosaceae species (Loescher, 1987). In this study, fruit removal resulted in accumulation of end products in leaves, while reducing the light period ("bag removal" treatments) decreased end product levels (Fig. 3). The short-term effects of weakening sink strength by fruit removal in the present study significantly decreased $\mathrm{P}_{\mathrm{n}}$. By contrast, removal of the bags covering the leaves had an effect similar to increasing sink strength, resulting in increased $\mathrm{P}_{\mathrm{n}}$ (Fig. 1A). Those effects of varying sink demand on $\mathrm{P}_{\mathrm{n}}, g_{\mathrm{s}}$, and $\mathrm{T}_{\text {leaf }}$ were similar to those reported in peach trees by Li et al. (2007) and Wu et al. (2008). 

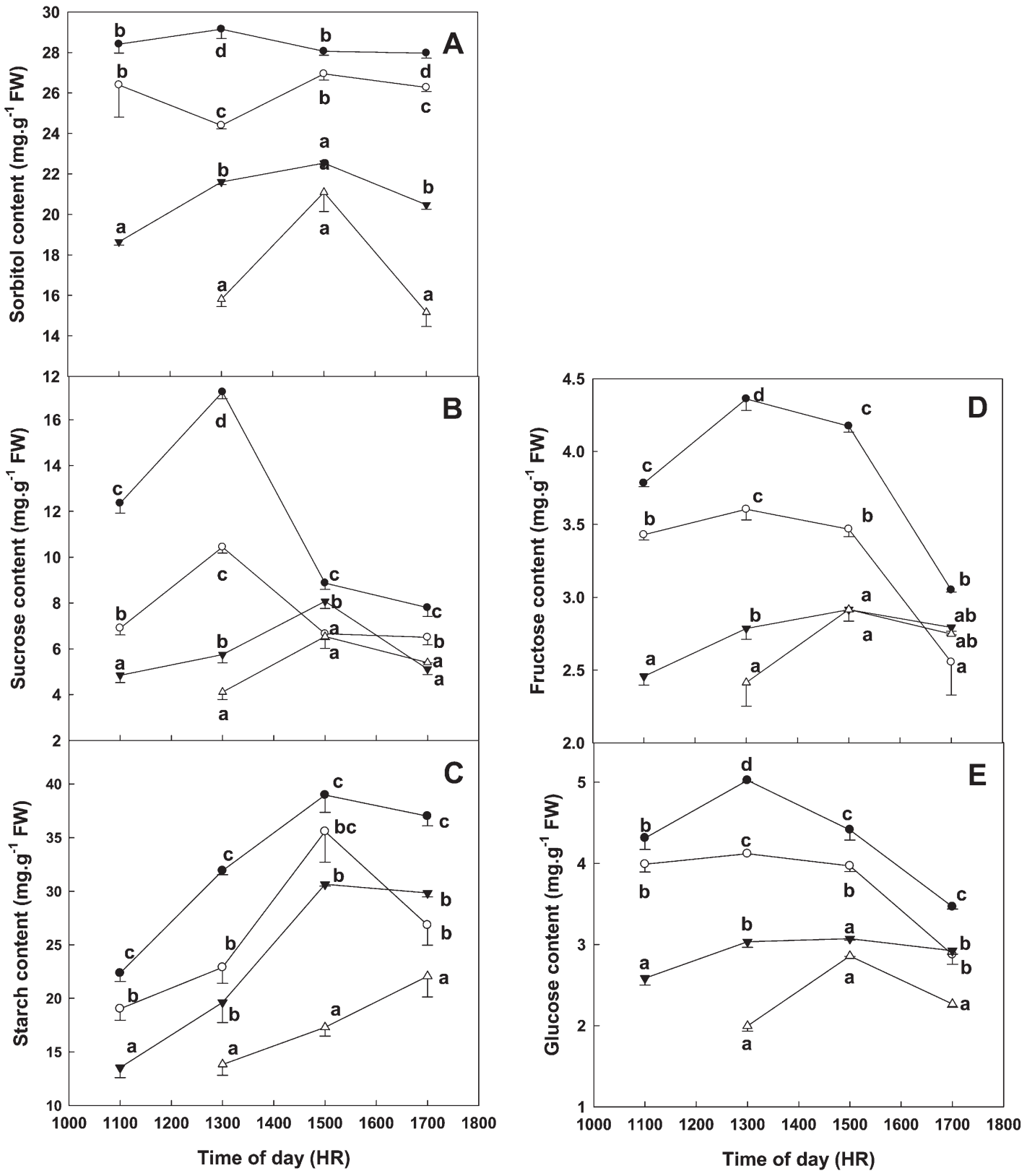

Fig. 3. Diurnal changes in foliar content of (A) sorbitol, (B) sucrose, (C) starch, (D) fructose, and (E) glucose in response to fruit removal ("-fruit", - - - ), "bag

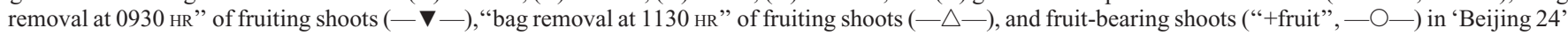
peach trees. Data were recorded on a fresh weight basis $\left(\mathrm{mg} \cdot \mathrm{g}^{-1}\right)$. The vertical bar represents \pm SE of each mean $(\mathrm{n}=5)$. Means with different letters at the same time point in the figure are significantly different among the treatments at $P<0.05$ based on Duncan's new multiple range test.

$\mathrm{P}_{\mathrm{n}}$ was related to the foliar amounts of the three end products in this study, decreasing as foliar end product levels increased (Fig. 6). Accumulation of end products in leaves is usually cited as the principal reason for lower photosynthesis under reduced sink demand, as a direct feedback mechanism (Iglesias et al., 2002; Layne and Flore, 1995). Consistent with this hypothesis, photosynthesis and the activity of related key biosynthetic enzymes should be depressed by end product accumulation with low sink demand ("-fruit") or enhanced when end products are low ("bag removal"). However, the present results indicate that key extractable enzyme activities did not change correspondingly. These enzyme activities did not decrease, and A6PR and SDH even increased at certain times during the day with low sink demand and high end product content (Fig. 4). In prior studies of peach (Li et al., 2007) and coffee (DaMatta et al., 2008), differences in $P_{n}$ also seemed unlikely to have been caused by photochemical impairments or a direct end product-mediated feedback down-regulation of photosynthesis. Given that in vitro enzyme activities were not influenced by foliar end product content, the modified photosynthetic rates created by source-sink manipulation may therefore be regulated by a mechanism other than direct feedback effects on related biosynthetic enzymes.

There was a positive linear relationship between $g_{\mathrm{s}}$ and $\mathrm{P}_{\mathrm{n}}$ in peach in previous studies (DeJong, 1986; Li et al., 2005, 2007; Tan and Buttery, 1986), as in the present study (Fig. 5B). Li 


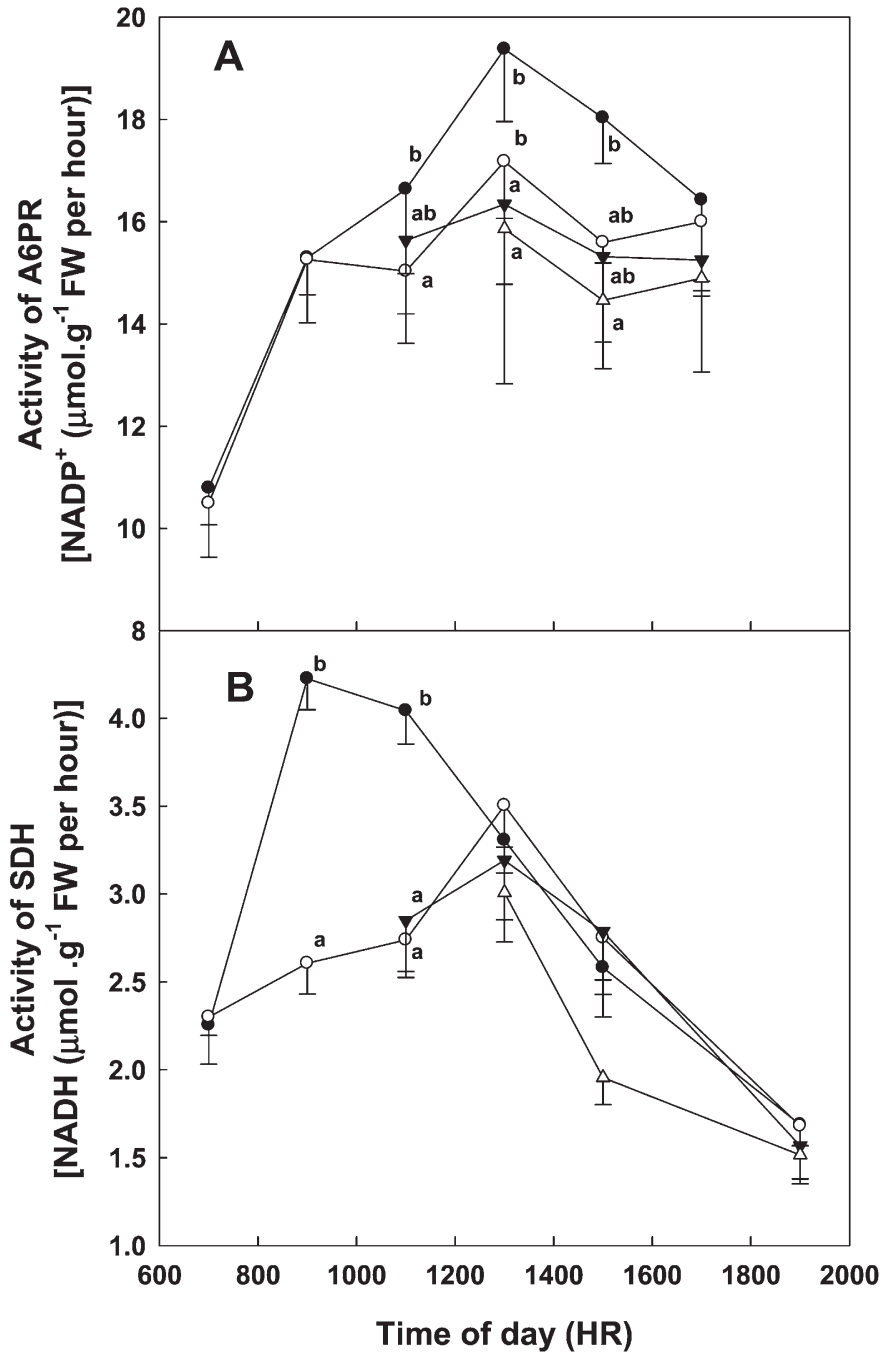

Fig. 4. Diurnal changes in activities of (A) aldose-6-phosphate reductase [NADP+ (mmol. $\mathrm{g}^{-1} \mathrm{FW}$ per hour)] (A6PR) and (B) sorbitol dehydrogenase [NADH (mmol. $\mathrm{g}^{-1} \mathrm{FW}$ per hour)] (SDH) in response to to fruit removal ("-fruit", - - -), "bag removal at $0930 \mathrm{HR}$ " of fruiting shoots ( $-\boldsymbol{\nabla}-)$, "bag removal at $1130 \mathrm{HR}$ " of fruiting shoots $(-\triangle-)$, and fruitbearing shoots ("+fruit", _- - ) in 'Beijing 24' peach trees. Data were recorded on a fresh weight basis. The vertical bar represents \pm SE of each mean $(\mathrm{n}=5)$. Means with different letters at the same time point in the figure are significantly different among the treatments at $P<0.05$ based on Duncan's new multiple range test or $t$ test (when there were only two treatments).

et al. (2001) suggested that stomatal aperture may be the trigger or promoter and leaf temperature the critical factor regulating photosynthesis when modifying source-sink relationships. In the present study, the different sink demands affected $g_{\mathrm{s}}$ and $\mathrm{E}$ (Fig. 1, B and C). $g_{\mathrm{s}}$ was negatively correlated with foliar end product content, especially that of starch (Fig. 7, A-C). Low $g_{\mathrm{s}}$ decreases leaf transpiration and therefore increases leaf temperature, which would influence photosynthesis (Li et al., 2001; $\mathrm{Li}$ et al., 2005). In the "-fruit" treatment, the high $\mathrm{T}_{\text {leaf }}$ was above the optimal level for the photosynthesis (Fig. 5A). High $\mathrm{T}_{\text {leaf }}$ results in damage to the photosynthesis apparatus and cell structure by the generation and accumulation of reactive oxygen species such as hydrogen peroxide $\left(\mathrm{H}_{2} \mathrm{O}_{2}\right)$ and malondialdehyde (MDA) (Duan et al., 2008). Damage to the photosynthetic apparatus and cell structure was confirmed by chlorophyll fluorescence results. Low sink demand by fruit
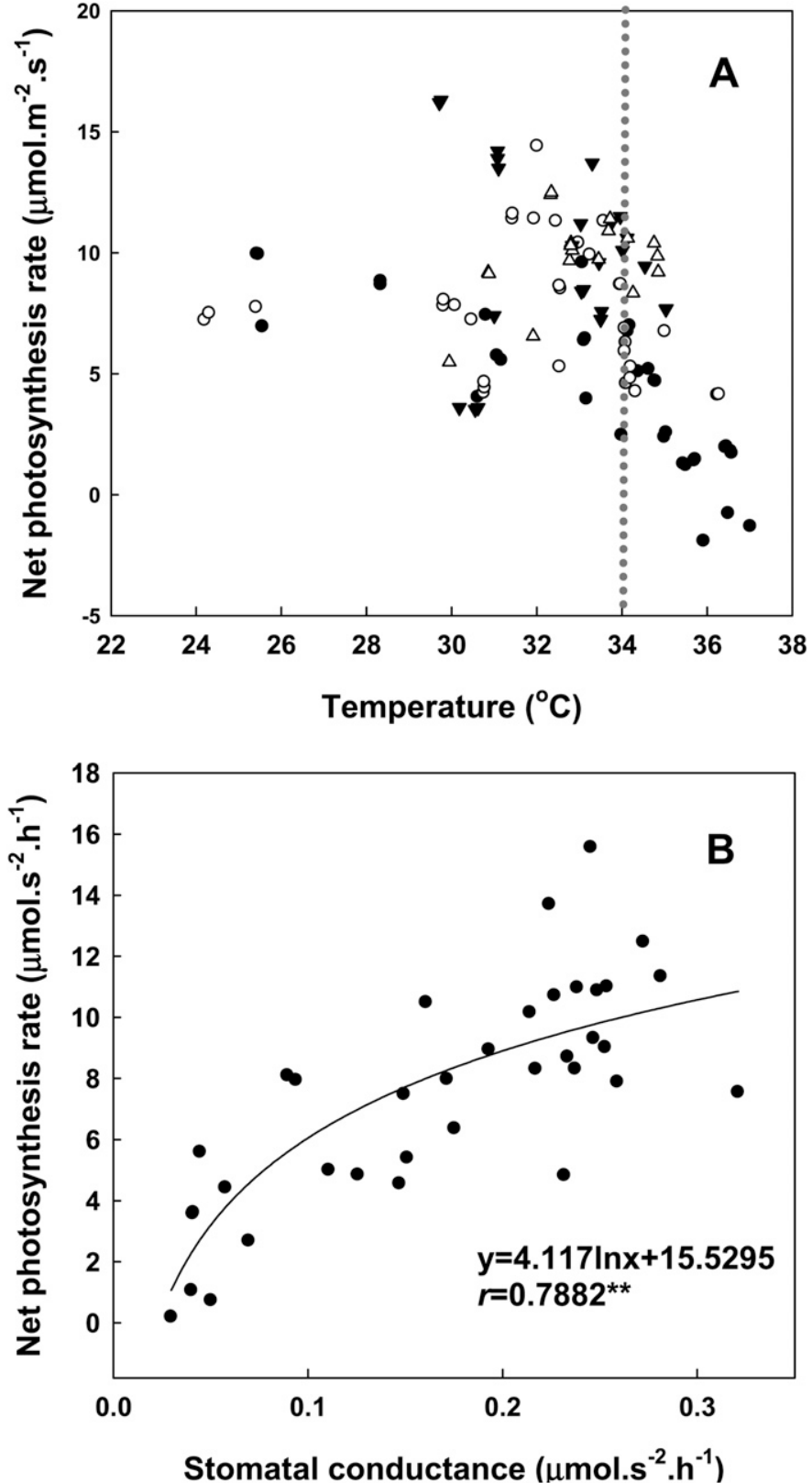

Fig. 5. Net photosynthetic rate $\left(\mathrm{P}_{\mathrm{n}}\right)$ in response to $(\mathbf{A})$ leaf temperature $\left(\mathrm{T}_{\text {leaf }}\right)$, and (B) $g_{\mathrm{S}}$ when leaf temperature exceeded $34^{\circ} \mathrm{C}$ in 'Beijing 24 ' peach trees. Symbols in A indicate fruit removal ("-fruit", —- - ), "bag removal at 0930 HR" of fruiting shoots (- - ), "bag removal at 1130 HR" of fruiting shoots $(-\triangle-)$, and fruit-bearing shoots ("+fruit", $-\bigcirc-)$; ** indicates significant correlation at $P<0.01$.

removal increased $\mathrm{F}_{0}$ throughout the day when compared with the "+fruit" and "bag removal" treatments (Fig. 2E), indicating damage to the PSII reaction center complex. $\mathrm{F}_{\mathrm{v}} / \mathrm{F}_{\mathrm{m}}$ represents electron transport efficiency and photochemical efficiency in the PSII reaction center. Layne and Flore (1995) reported that continuous lighting significantly reduced $\mathrm{F}_{\mathrm{v}}$ and $\mathrm{F}_{\mathrm{v}} / \mathrm{F}_{\mathrm{m}}$ within $1 \mathrm{~d}$ in sour cherry (Prunus cerasus $\mathrm{L}$.). The decline in $\mathrm{F}_{\mathrm{v}} / \mathrm{F}_{\mathrm{m}}$ observed in "-fruit" leaves (Fig. 2A) was presumably related to increased dissipation of excess energy.

$\mathrm{P}_{\mathrm{n}}$ was significantly correlated with $g_{\mathrm{s}}$ (Fig. 5B), and the latter was correlated with end product levels (Fig. 7), indicating that end product accumulation may affect $\mathrm{P}_{\mathrm{n}}$ via altering $g_{\mathrm{s}}$. In 

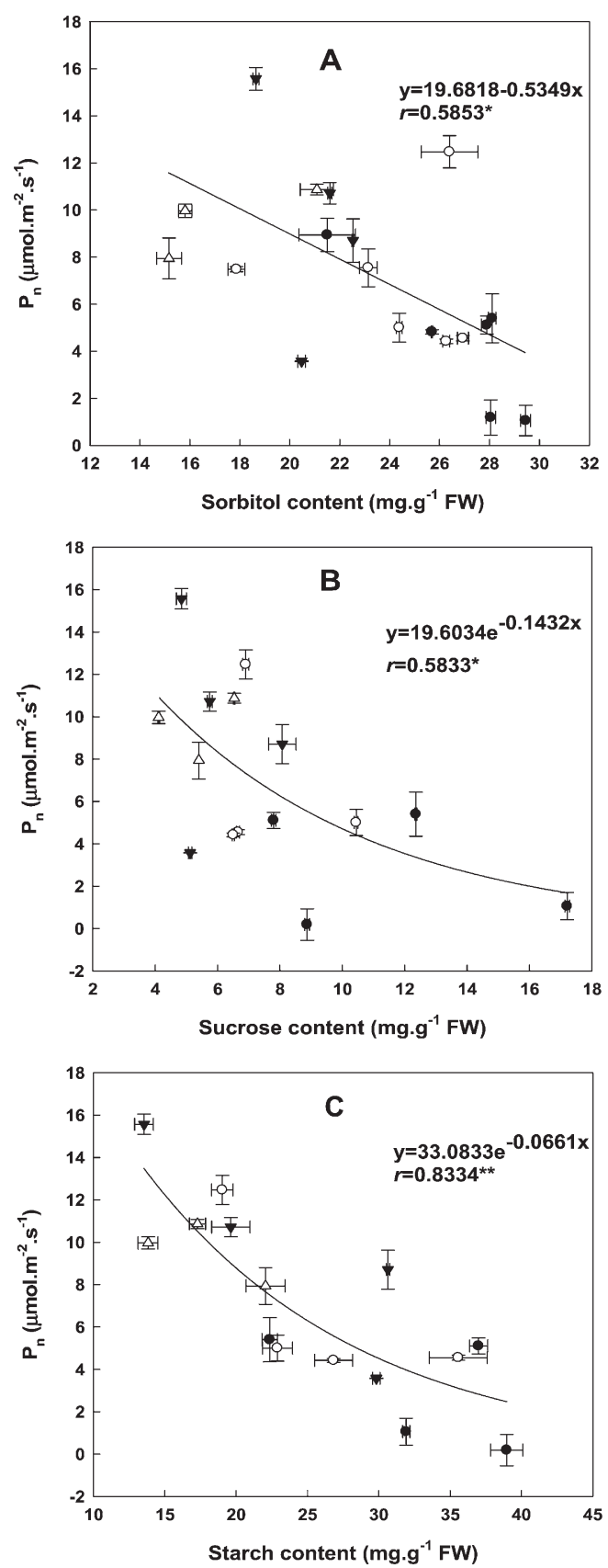

Fig. 6. Response of net photosynthetic rate $\left(\mathrm{P}_{\mathrm{n}}\right)$ to foliar content of (A) sorbitol, (B) sucrose, and (C) starch in 'Beijing 24' peach trees. Symbols indicate fruit removal ("-fruit", - - - "), "bag removal at $0930 \mathrm{HR}$ " of fruiting shoots ( $-\boldsymbol{\nabla}-)$, "bag removal at $1130 \mathrm{HR}$ " of fruiting shoots $(-\triangle-)$, and fruitbearing shoots ("+fruit", - $\bigcirc-$ ). End product content data were recorded on a fresh weight basis $\left(\mathrm{mg} \cdot \mathrm{g}^{-1}\right)$. Each point is mean \pm SE for foliar content of individual end products (horizontal, $\mathrm{n}=5$ ) and $\mathrm{P}_{\mathrm{n}}($ vertical, $\mathrm{n}=5$ ); * or ** indicate significant correlation at $P<0.05$ or $P<0.01$, respectively.

addition, end product accumulation may also affect photochemical efficiency. ФPSII decreased as end products increased (Fig. 8), while NPQ increased (Fig. 9). High $\mathrm{P}_{\mathrm{n}}$ at low end product content could be explained by high $\Phi \mathrm{PSII}$ and low NPQ. ФPSII is the product of $\mathrm{qP}$ and $\mathrm{F}_{\mathrm{v}}{ }^{\prime} / \mathrm{F}_{\mathrm{m}}{ }^{\prime}$ in open PSII centers (Genty et al., 1989), so increased $\Phi$ PSII could be due to an increase in photochemical quenching and $\mathrm{F}_{\mathrm{v}}{ }^{\prime} / \mathrm{F}_{\mathrm{m}}{ }^{\prime}$. NPQ has usually been used as an indicator of the appearance in the
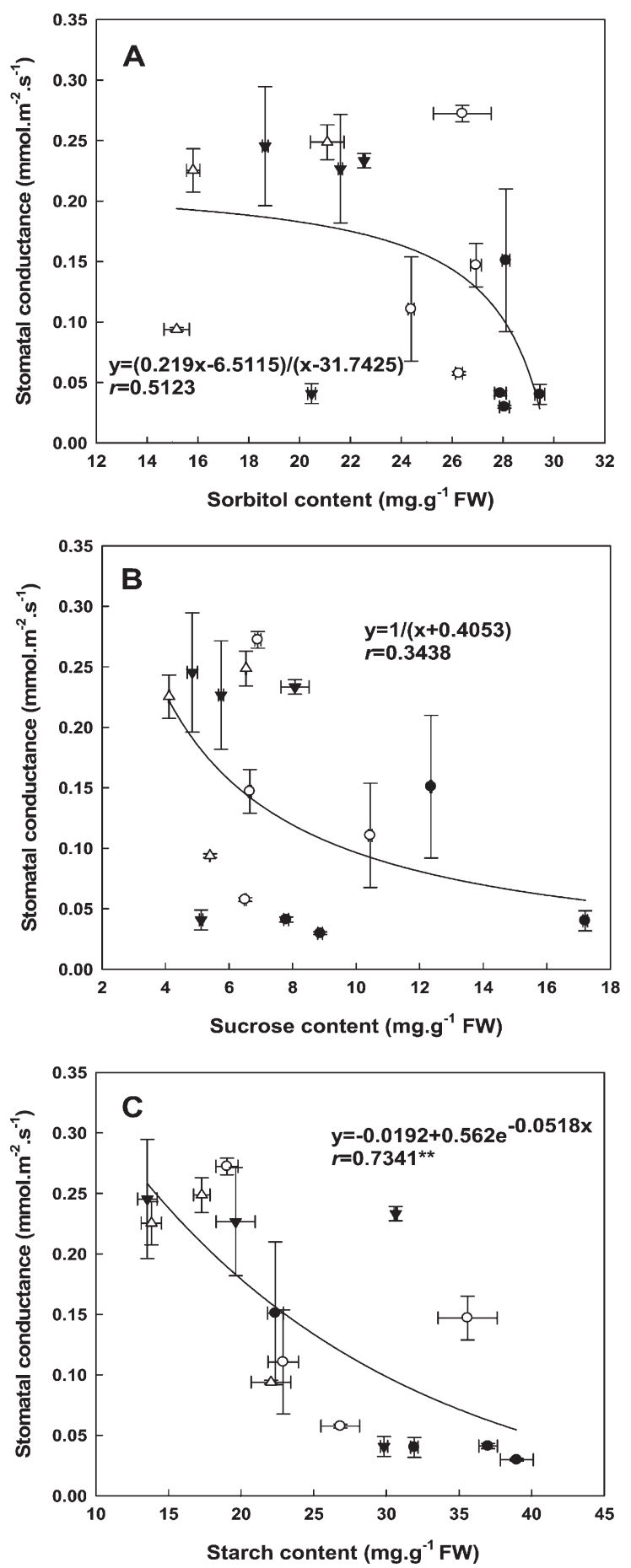

Fig. 7. Stomatal conductance $\left(g_{\mathrm{s}}\right)$ response to foliar content of (A) sorbitol, (B) sucrose, and (C) starch in 'Beijing 24' peach trees. Symbols indicate fruit removal ("-fruit", - - ), "bag removal at $0930 \mathrm{HR}$ " of fruiting shoots ( $-\boldsymbol{\nabla}-)$, "bag removal at $1130 \mathrm{HR}$ " of fruiting shoots $(-\triangle-)$, and fruitbearing shoots ("+fruit", - $\bigcirc-$ ). End product content data were recorded on a fresh weight basis $\left(\mathrm{mg} \cdot \mathrm{g}^{-1} \mathrm{FW}\right)$. Each point is mean \pm SE for foliar content of individual end products (horizontal, $\mathrm{n}=5$ ) and $g_{\mathrm{s}}($ vertical, $\mathrm{n}=5$ ); ** indicates significant correlation at $P<0.01$.

photosynthetic apparatus of mechanisms to prevent overexcitation of reaction centers (Ivanov and Edwards, 2000). Leaves with lower end product levels had higher photosynthetic capacity, so they use a bigger fraction of the absorbed light in 

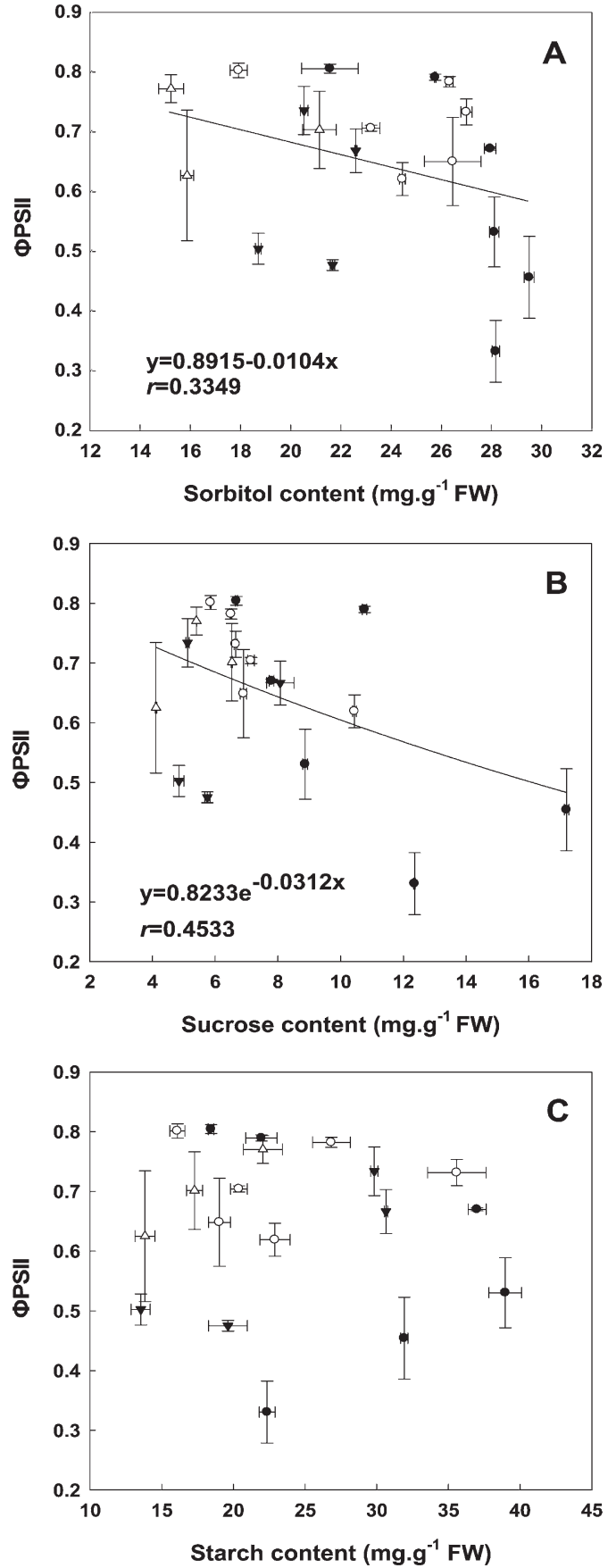

Fig. 8. Actual photochemical efficiency of PSII in response to foliar content of (A) sorbitol, (B) sucrose, and (C) starch in 'Beijing 24' peach trees. Symbols indicate fruit removal ("-fruit", _- - ), "bag removal at $0930 \mathrm{HR}$ " of fruiting shoots ( $-\mathbf{\nabla}-)$, "bag removal at $1130 \mathrm{HR}$ " of fruiting shoots $(-\triangle-)$, and fruit-bearing shoots ("+fruit", - $\bigcirc-$ ). End product content data were recorded on a fresh weight basis $\left(\mathrm{mg} \cdot \mathrm{g}^{-1}\right)$. Each point is mean $\pm \mathrm{SE}$ for foliar content of individual end product (horizontal, $\mathrm{n}=5$ ) and ФPSII (vertical, $\mathrm{n}=5$ ).

electron transport. As a result, there was less thermal dissipation of excitation energy.

In conclusion, accumulation of end products in leaves decreased $\mathrm{P}_{\mathrm{n}}, g_{\mathrm{s}}$, and $\mathrm{E}$, but increased $\mathrm{T}_{\text {leaf }}$, in peach leaves. However, high foliar end product content had no direct feedback effect on the activities of related enzymes of carbon metabolism in vitro. Thus, changes in $P_{n}$ in response to accumulation of
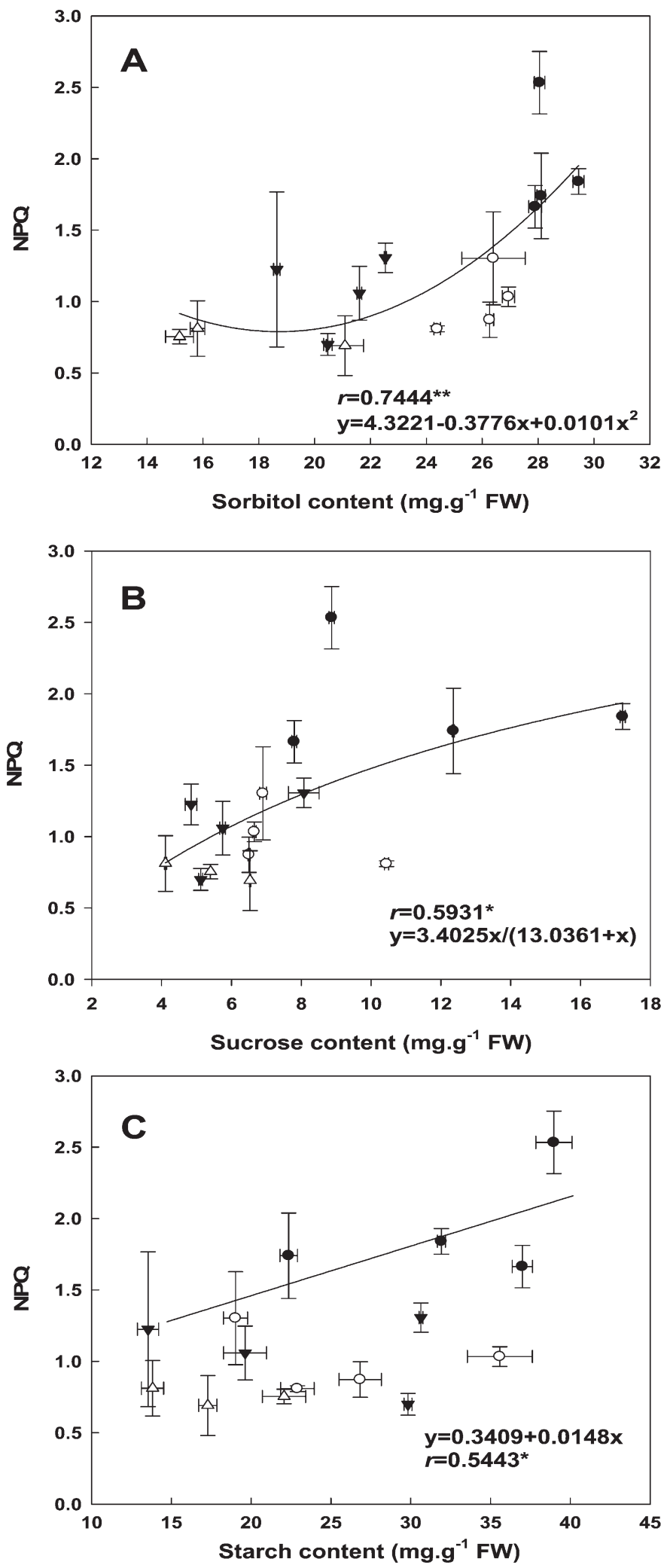

Fig. 9. Response of nonphotochemical quenching (NPQ) to foliar content of (A) sorbitol, (B) sucrose, and (C) starch in 'Beijing 24' peach trees. Symbols indicate to fruit removal ("-fruit", _- - " "bag removal at $0930 \mathrm{HR}$ " of fruiting shoots ( $-\mathbf{\nabla}-)$, "bag removal at $1130 \mathrm{HR}$ " of fruiting shoots $(-\triangle-)$, and fruit-bearing shoots ("+fruit", - $\bigcirc-$ ). End product content data were recorded on a fresh weight basis $\left(\mathrm{mg}^{-1} \mathrm{~g}^{-1}\right)$. Each point is mean $\pm \mathrm{SE}$ for foliar content of individual end product (horizontal, $\mathrm{n}=5$ ) and NPQ (vertical, $\mathrm{n}=5$ ); * or ** indicate significant correlation at $P<0.05$ or $P<0.01$, respectively. 
end products may result from a negative effect on photosynthetic efficiency. Stomatal aperture may start to close as the initial response and thus affect $P_{n}$. Accumulated soluble sugar and starch in leaves may change osmotic pressure of the guard cells, resulting in such a $g_{\text {s }}$ change. End products may also act as signals, with crosstalk with phytohormones such as abscisic acid (ABA) (Gibson, 2005; Lloyd and Zakhleniuk, 2004; Roitsch, 1999). End product accumulation may also affect photochemical efficiency, changing $\mathrm{F}_{0}, \mathrm{~F}_{\mathrm{v}} / \mathrm{F}_{\mathrm{m}}$, and ФPSII. However, it will be necessary to focus on the mechanism of end product alteration of stomatal movement for understanding the effect on $\mathrm{P}_{\mathrm{n}}$. Also, the possibility that accumulation of end products may down-regulate photosynthesis in peach leaves by deactivating some of the key enzymes in carbon fixation, such as Rubisco, should be studied in the future.

\section{Literature Cited}

Cheng, Y.H., O. Arakawa, M. Kasai, and S. Sawada. 2008. Analysis of reduced photosynthesis in the apple leaf under sink-limited conditions due to girdling. J. Jpn. Soc. Hort. Sci. 77:115-121.

DaMatta, F.M., R.L. Cunha, W.C. Antunes, S.C.V. Martins, W.L. Araujo, A.R. Fernie, and G.A.B.K. Moraes. 2008. In field-grown coffee trees source-sink manipulation alters photosynthetic rates, independently of carbon metabolism, via alterations in stomatal function. New Phytol. 178:348-357.

DeJong, T.M. 1986. Fruit effects on photosynthesis in Prunus persica. Physiol. Plant. 66:149-153.

Duan, W., P.G. Fan, L.J. Wang, W.D. Li, S.T. Yan, and S.H. Li. 2008. Photosynthesis response to low sink demand by fruit removal in relation to photochemistry efficiency, photoinhibition, and photoprotection in peach trees. Tree Physiol. 28:123-132.

Eliezer, E.G. and S.C. Huber. 1992. Regulation of photosynthesis by end product accumulation in leaves of plants storing starch, sucrose, and hexose sugars. Plant Physiol. 99:1443-1448.

Genty, B., J.M. Briantais, and N.R. Baker. 1989. The relationship between the quantum yield of photosynthetic electron transport and quenching of chlorophyll fluorescence. Biochim. Biophys. Acta 990: 87-92.

Gibson, S.I. 2005. Control of plant development and gene expression by sugar signaling. Curr. Opin. Plant Biol. 8:93-102.

Huber, S.C. and D.W. Israel. 1982. Biochemical basis for partitioning of photosynthetically fixed carbon between starch and sucrose in soybean (Glycine max Merr.) leaves. Plant Physiol. 69:691-696.

Iglesias, D.J., I. Lliso, F.R. Tadeo, and M. Talon. 2002. Regulation of photosynthesis through source: Sink imbalance in citrus is mediated by carbohydrate content in leaves. Physiol. Plant. 116:563-572.

Ivanov, B. and G. Edwards. 2000. Influence of ascorbate and the Mehler peroxidase reaction on non-photochemical quenching of chlorophyll fluorescence in maize mesophyll chloroplasts. Planta 210:765-774.

Jifon, J.L. and J.P. Syvertsen. 2003. Moderate shade can increase net gas exchange and reduce photoinhibition in citrus leaves. Tree Physiol. 23:119-127.

Layne, D.R. and J.A. Flore. 1995. End-product inhibition of photosynthesis in Prunus cerasus L. in response to whole-plant sourcesink manipulation. J. Amer. Soc. Hort. Sci. 120:583-599.

Li, S.H., M. Génard, C. Bussi, J.G. Huguet, R. Habib, J. Besset, and R. Laurent. 2001. Fruit quality and leaf photosynthesis in response to microenvironment modification around individual fruit by covering the fruit with plastic in nectarine and peach trees. J. Hort. Sci. Biotechnol. 76:61-69.
Li, S.H., X.P. Zhang, Z.Q. Meng, and X. Wang. 1994. Response of peach tree to modified pruning. I. Vegetative growth. N. Z. J. Crop Hort. Sci. 22:401-409.

Li, T.H. and S.H. Li. 2005. Leaf responses of micropropagated apple plants to water stress: Nonstructural carbohydrate composition and regulatory role of metabolic enzymes. Tree Physiol. 25:495-504.

Li, W.D., S.H. Li, S.H. Yang, J.M. Yang, X.B. Zheng, X.D. Li, and H.M. Yao. 2005. Photosynthesis in response to source-sink manipulation during different phenological stages of fruit development in peach trees: Regulation by stomatal aperture and leaf temperature. J. Hort. Sci. Biotechnol. 80:481-487.

Li, W.D., W. Duan, P.G. Fan, S.T. Yan, and S.H. Li. 2007. Photosynthesis in response to source-sink activity and in relation to end products and activities of metabolic enzymes in peach trees. Tree Physiol. 27:1307-1318.

Lloyd, J.C. and O.V. Zakhleniuk. 2004. Responses of primary and secondary metabolism to sugar accumulation revealed by microarray expression analysis of the arabidopsis mutant, pho3. J. Expt. Bot. 55:1221-1230.

Loescher, W.H. 1987. Physiology and metabolism of sugars alcohols in higher plants. Physiol. Plant. 70:553-557.

Lunn, J.E. and M.D. Hatch. 1995. Primary partitioning and storage of photosynthate in sucrose and starch in leaves of $\mathrm{C}_{4}$ plants. Planta 197:385-391.

Merlo, L. and C. Passera. 1991. Changes in carbohydrate and enzyme levels during development of leaves of Prunus persica, a sorbitol synthesizing species. Physiol. Plant. 83:621-626.

Nautiyal, P.C., V. Ravindra, and Y.C. Joshi. 1999. Net photosynthetic rate in peanut (Arachis hypogaea L.): Influence of leaf position, time of day, and reproductive-sink. Photosynthetica 36:129-138.

Negm, F.B. and W.H. Loescher. 1979. Detection and characterization of sorbitol dehydrogenase from apple callus tissue. Plant Physiol. 64: 69-73.

Paul, M.J. and C.H. Foyer. 2001. Sink regulation of photosynthesis. J. Expt. Bot. 52:1383-1400.

Paul, M.J. and T.K. Pellny. 2003. Carbon metabolite feedback regulation of leaf photosynthesis and development. J. Expt. Bot. 54: 539-547.

Roitsch, T. 1999. Source-sink regulation by sugar and stress. Curr. Opin. Plant Biol. 2:198-206.

Roper, T.R., J.D. Keller, W.H. Loescher, and C.R. Rom. 1988. Photosynthesis and carbohydrate partitioning in sweet cherry: Fruiting effects. Physiol. Plant. 72:42-47.

Rufty, T.W., P.S. Kerr, and S.C. Huber. 1983. Characterization of diurnal changes in activities of enzymes involved in sucrose biosynthesis. Plant Physiol. 73:428-433.

Stitt, M. 1991. Raising $\mathrm{CO}_{2}$ levels and their potential significance for carbon flow in photosynthetic cells. Plant Cell Environ. 14:741-762.

Syvertsen, J.P., C. Goni, and A. Otero. 2003. Fruit load and canopy shading affect leaf characteristics and net gas exchange of 'Spring' navel orange trees. Tree Physiol. 23:899-906.

Tan, C.S. and B.R. Buttery. 1986. Photosynthesis, stomatal conductance, and leaf water potential in response to temperature and light in peach. HortScience 21:1180-1182.

Vaast, P., J. Angrand, N. Franck, J. Dauzat, and M. Génard. 2005. Fruit load and branch ring-barking affect carbon allocation and photosynthesis of leaf and fruit of Coffea arabica in the field. Tree Physiol. 25:753-760.

Wu, B.H., H.Q. Huang, P.G. Fan, S.H. Li, and G.J. Liu. 2008. Photosynthetic responses to source-sink manipulation in five peach cultivars varying in maturity date. J. Amer. Soc. Hort. Sci. 133:278-283.

Zhou, R. and B. Quebedeaux. 2003. Changes in photosynthesis and carbohydrate metabolism in mature apple leaves in response to whole plant source-sink manipulation. J. Amer. Soc. Hort. Sci. 128:113-119. 